\title{
O planejamento governamental como discurso: tensões entre política e técnica (1930-2003)
}

\author{
Bruno Moretti \\ Orientador: Mariza Veloso Motta Santos \\ Tese de Doutorado \\ Data da defesa: 30.07.2012
}

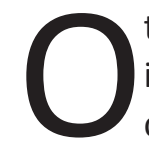

trabalho tem por objetivo abordar o planejamento como discurso no interior do Estado, cujos enunciados procuram obter o crédito da racionalização da atividade estatal, conferindo-lhe o poder de definir, por exemplo, os critérios para o bom gasto público. Essa distinção ganhará formas específicas, de acordo com os modelos de Estado construídos historicamente no Brasil. Estes procuram obter legitimidade a partir de sentidos do interesse geral, predicados a categorias como "modernização" e "desenvolvimento". A tese parte da perspectiva de que tais linguagens, ao se tornarem oficiais, convertem-se em práticas institucionais. Estas constroem o espaço de possibilidades para a intervenção estatal, definindo o que é ou não possível de se fazer e dizer. O foco do trabalho é a Reforma do Estado da década de 1990. Sua mensagem é que o Brasil é um país cujos problemas decorrem da persistência dos fatores de atraso que o impedem de ser uma nação moderna. Esses fatores se concentram num Estado definido como patrimonial e burocrático. Assim, o sentido que a Reforma atribui ao interesse coletivo autoriza a dissolução das estruturas intervencionistas construídas entre 1930 e 1980, nas quais o planejamento teve papel central. Em seu lugar, seria organizado um Estado voltado à eficiência, praticando uma administração por resultados, focada nos interesses dos cidadãos, negando a si própria como uma posição de valor e identificando-se como racional e desapaixonada. Sua eficácia reside em sua transposição para um sistema de práticas, que, ao mesmo tempo, denegam seu conteúdo valorativo e realizam a interpretação do Estado como fonte dos problemas nacionais - o Estado como negatividade. Enfim, a interpretação passa a ser válida na medida em que monopoliza o sentido do bem comum, inscrevendo-se como pontos de controle do processamento de demandas sociais e induzindo a atitudes de controle e prudência que refratam, para o cotidiano das práticas estatais (particularmente, o planejamento), um sistema causal que articula Estado e ineficiência. É nesse contexto que será retomado o planejamento governamental, atualizando seu pleito de filtro racionalizante, agora, não mais construído como ferramenta para ampliar a intervenção estatal, mas como procedimentos que reivindicam o compromisso axiologicamente neutro com o gerenciamento por resultados, paradoxalmente compondo o conjunto de 
técnicas autorizadas a exercer o controle das ações estatais e restringir seu próprio espaço de possibilidades, cristalizando o imaginário do Estado como negatividade.

Palavras-chave: Planejamento, Estado, Interesse Coletivo, Desenvolvimento, Modernização, Reforma do Estado, Discurso, Burocracia, Eficácia Instrumental. 